\title{
Non-Metastatic Neoplasm
}

National Cancer Institute

\section{Source}

National Cancer Institute. Non-Metastatic Neoplasm. NCI Thesaurus. Code C36037.

A neoplasm that is confined to the site in which it initially manifested. 